\title{
Down-regulation of the expression of CCAAT/ enhancer binding protein a gene in cervical squamous cell carcinoma
}

Zemin Pan ${ }^{1,2^{*}}$, Weinan Zheng ${ }^{1,2}$, Jinli Zhang ${ }^{1,2}$, Rui Gao ${ }^{1,2}$, Dongmei Li ${ }^{1}$, Xiaoqing Guo ${ }^{1}$, Hu Han ${ }^{1}$, Feng Li ${ }^{1}$, Shen $\mathrm{Qu}^{2}$ and Renfu Shao ${ }^{3}$

\begin{abstract}
Background: Cervical carcinoma is the second most common cancer and is an important cause of death in women worldwide. CCAAT/enhancer binding proteins (C/EBPs) are a family of transcription factors that regulate cellular differentiation and proliferation in a variety of tissues. However, the role of C/EBPa gene in cervical cancer is still not clear.

Methods: We investigated the expression of C/EBPa gene in cervical squamous cell carcinoma. C/EBPa mRNA level was measured by real-time quantitative RT-PCR in cervical cancer tissues and their adjacent normal tissues. C/EBPa protein level was measured by immunohistochemistry. Methylation in the promoter of C/EBPa gene was detected by MALDI TOF MassARRAY. We transfected HeLa cells with C/EBPa expression vector. C/EBPa expression in HeLa cells was examined and HeLa cell proliferation was measured by MTT assay and HeLa cells migration was analyzed by matrigel-coated transwell migration assays.
\end{abstract}

Results: There were significant difference in C/EBPa protein expression between chronic cervicitis and cervical carcinoma $(P<0.001)$. CEBPa mRNA level was significantly lower in cervical cancer tissues than in normal cervical tissues $(P<0.01)$. Methylation of the promoter of CEBPa gene in CpG 5, CpG-14.15, CpG-19.20 were significantly higher in cervical cancer than in normal cervical tissues $(P<0.05, P<0.01, P<0.05$, respectively). CEBPa pcDNA3.1 construct transfected into HeLa cells inhibited cell proliferation and decreased cell migration.

Conclusions: Our results indicate that reduced C/EBPa gene expression may play a role in the development of cervical squamous cell carcinoma.

Keywords: C/EBPa gene, Gene expression, Cervical squamous cell carcinoma

\section{Background}

Cervical carcinoma is the second most common cancer and is an important cause of death in women worldwide [1]. The incidence and mortality of cervical cancer have decreased gradually in the past decades globally. In China, however, the incidence of cervical cancer remains high, particularly in young women [2].

\footnotetext{
*Correspondence: panteacher89@sina.com

'Department of Biochemistry and Molecular Biology, School of Medicine, Shihezi University, Xinjiang Endemic and Ethnic Disease and Education Ministry Key Laboratory, Shihezi, Xinjiang 832002, China

${ }^{2}$ Department of Biochemistry and Molecular Biology, Basic Medical Science of Tongji Medical College, Huazhong University of Science and Technology, Wuhan, Hubei 430030, China

Full list of author information is available at the end of the article
}

CCAAT/enhancer binding proteins (C/EBPs) are a family of transcription factors with six members, $\alpha$ to $\zeta$; C/EBPs regulate cellular differentiation in a variety of tissues [3]. Each C/EBP consists of an activation domain, a DNA-binding domain, and a leucine-rich dimerization domain. C/EBP $\alpha$ protein interacts with several cell-cycle regulatory proteins; such interaction can inhibit cell proliferation. For instance, C/EBP $\alpha$ interacts with retinoblastoma $(\mathrm{Rb})$ family proteins and inhibits cell growth [4]. Studies showed that C/EBP $\alpha$ can form a complex with cyclin-dependent kinase 2 (cdk2) and cyclin-dependent kinase 4 (cdk4) proteins and block cyclin-cdk interactions and cell cycle progression [5]. Aberrant expression of $C /$ $E B P \alpha$ in Trib1-deficient bone marrow cells is responsible 
for the defects in macrophage differentiation [6]. In addition, it was suggested that high levels of $C / E B P \alpha$ accelerate both the switching process and the cell growth arrest [7]. C/EBP $\alpha$ gene was down-regulated in many tumors such as skin carcinomas, breast cancer and lung cancer [8]. C/EBP $\alpha$ gene as a lung tumor suppressor was demonstrated: loss of $C / E B P \alpha$ expression through p $38 \alpha$ inactivation led to tumor promotion and progression [9].

In our early work, we used suppression subtractive hybridization method and found $C / E B P \alpha$ gene expression changed in cervical carcinoma tissues [10]. In addition, Ko found that $C / E B P \delta$ gene expression level decreased in cervical cancer [11]. We show here that $C /$ $E B P \alpha$ gene is also down-regulated in cervical squamous cell carcinoma (CSCC).

\section{Methods}

\section{Sample collection}

Clinical data and cervical squamous cell carcinoma samples were collected from patients at the First Affiliated Hospital and the Third Affiliated Hospital of the Medical College of Shihezi University, Xinjiang, China between January 2008 and April 2012. Cervical cancer samples were taken for every consecutive patient with different grades of pathology. None of these patients received chemotherapy or radiotherapy before the cervical tissue samples were obtained. All histological diagnoses were confirmed by experienced pathologists in the hospitals. Written informed consent was obtained from each patient; approval was obtained from the Ethics Committee of the Medical College of Shihezi University, China. Cervical squamous cell carcinoma tissues and adjacent normal cervical tissues were collected together from each patient. Tissue samples were snap-frozen immediately after removal and were stored at $-80^{\circ} \mathrm{C}$.

\section{Immunohistochemistry staining}

Representative formalin fixed paraffin-embedded tissue blocks were selected. Five $\mu \mathrm{m}$ sections were cut, deparaffinised and rehydrated through graded alcohols. Antigen retrieval was performed by heating the slides in citrate buffer at $98^{\circ} \mathrm{C}$ for $30 \mathrm{~min}$ in a water bath. Endogenous peroxidase was quenched for $10 \mathrm{~min}$ with peroxidase blocking reagent (Dako Corporation). Primary antibodies, anti-C/EBP $\alpha$ (1:200; sc-61, Santa Cruz Biotechnology) and anti-Ki-67 (1:100; BD Biosciences Pharmingen) were incubated for $60 \mathrm{~min}$ at room temperature. Antibody staining was visualized using the ChemMate Envision detection system (Dako Cytomation). Sections were counterstained. The counterstaining was performed with Meyer's hematoxylin solution. Negative controls were run simultaneously with preimmune immunoglobulin. Rabbit polyclonal antibody (Ab-1) used was diluted 10- and 50- fold. The specificity of the immunohistochemical reactions was assessed by performing the assays in the presence of an excess of relevant versus irrelevant peptides. The peptide used for immunization completely suppressed staining whereas an irrelevant peptide at the same concentration had no effect. The C/EBP $\alpha$ protein and $\mathrm{Ki}-67$ protein $\mathrm{IHC}$ signal was scored on the following scale taking into account both the proportion of cells stained and the intensity of staining in those cells as follows: score 0 , no cells stained; score 1 , weak or absent nuclear staining and $<5 \%$ of cells containing $\mathrm{C} / \mathrm{EBP} \alpha$ and $\mathrm{Ki}-67$ localized to the nuclei of cells; score 2, nuclear staining and between $5 \%$ and $25 \%$ of the cells containing $\mathrm{C} / \mathrm{EBP} \alpha$ and $\mathrm{Ki}-67$ localized prominently to the nuclei of cells; score 3 , nuclear staining and between $26 \%$ and $50 \%$ of the cells containing C/ EBP $\alpha$ and Ki-67 localized prominently to the nuclei of cells; score 4 , nuclear staining and more than $50 \%$ of the cells containing $\mathrm{C} / \mathrm{EBP} \alpha$ and Ki-67 localized prominently to the nuclei of cells. Two observers quantified independently.

\section{Quantitative reverse transcription-PCR (qRT-PCR)}

Total RNA was isolated from cervical squamous cell carcinoma tissues and their adjacent normal tissues using the RNA Extraction Kit (Invitrogen). cDNA were synthesized with Invitrogen's SuperScript One-Step RT-PCR Kit; each reaction contained $2 \mu \mathrm{g}$ total RNA, $2 \mu \mathrm{l}$ Oligo (dT) $(500 \mu \mathrm{g} / \mathrm{ml})$, and $7.5 \mu \mathrm{l}$ DEPC water. Reactions were heated for denaturation at $65^{\circ} \mathrm{C}$ for $5 \mathrm{~min}$, then quenched on ice for $5 \mathrm{~min}$. The following reagents were then added to each reaction: $4 \mu \mathrm{l} 5 \times 1$ st Buffer, $2 \mathrm{ul} 0.1$ M DTT, $1 \mu \mathrm{l}$ dNTPs (10 mM each), $0.5 \mu l$ RNase Inhibitor (40 U/ $\mu \mathrm{l}), 1 \mu \mathrm{l}$ M-MLV $(200 \mathrm{U} / \mu \mathrm{l})$; the total volume of each reaction was $20 \mu \mathrm{l}$. The reactions were kept at $25^{\circ} \mathrm{C}$ for $10 \mathrm{~min}, 37^{\circ} \mathrm{C} 1 \mathrm{~h}$, and then $70^{\circ} \mathrm{C}$ for 10 min to terminate the reaction. $C / E B P \alpha$ mRNA level was determined by real-time RT-PCR using a Light $\mathrm{Cy}$ cler 480 (Roche Diagnostics) with the forward primer, 5'-AACACGAAGCACGATCAGTCC-3', and the reverse primer, 5' -CTCATTTTGGCAAGTATCCGA-3'. The amplicons were $211 \mathrm{bp}$ in size. To normalize the amount of cDNA in each sample, the housekeeping gene aldehyde-3-phosphate dehydrogenase (GAPDH) was quantified on the control of experiment with specific primers (forward: 5 '-TGTTGCCATCAATGAC CCCTT-3'; reverse: 5'-CTCCACGACGTACTCAGC G-3'); the amplicons were $202 \mathrm{bp}$. Each reaction contained cDNA $500 \mathrm{ng}, 2 \times$ PCR buffer for EvaGreen $10 \mu \mathrm{l}$, $20 \times$ EvaGreen $0.6 \mu \mathrm{l}$, forward primer and reverse primer were $0.6 \mu \mathrm{l}(10 \mathrm{uM} /)$ respectively, Cap Taq polymerase 0.3 $\mu \mathrm{l}(5 \mathrm{U} / \mu \mathrm{l})$; add DEPC water to $20 \mu \mathrm{l}$. Reaction conditions were: initial denaturation for $5 \mathrm{~min}$ at $95^{\circ} \mathrm{C}$; then 40 cycles of denaturation for $15 \mathrm{sec}$ at $95^{\circ} \mathrm{C}$, primer annealing 
for $15 \mathrm{sec}$ at $55^{\circ} \mathrm{C}$, extension for $20 \mathrm{sec}$ at $72^{\circ} \mathrm{C}$, and UPL fluorescence measurement for $3 \mathrm{sec}$ at $76^{\circ} \mathrm{C}$.

\section{Gene methylation analysis by matrix assisted laser desorption ionization time of flight MassARRAY (MALDI- TOF MassARRAY)}

Gene methylation was analyzed using MALDI-TOF MassARRAY method [12]. DNA from cervical tissue samples was extracted using QIAamp DNA Mini Kit (QIAGEN). Bisulfite treatment was performed using EZ DNA methylation kit (Sequenom, USA). PCR was performed in a total volume of $5 \mu \mathrm{l}$ containing $0.5 \mathrm{U}$ Hot Star Taq polymerase (Qiagen), 10 pmol of forward and reverse primers $0.5 \mu \mathrm{l}, 10 \times \mathrm{PCR}$ buffer $\left(\mathrm{Mg}^{2+}\right.$ free) 0.5 $\mu \mathrm{l}, \mathrm{ddH}_{2} \mathrm{O} 0.5 \mu \mathrm{l}, \mathrm{MgCl}_{2} 0.4 \mu \mathrm{l}, 25 \mathrm{mM}$ dNTP $0.1 \mu \mathrm{l}$ and $5 \mathrm{ng}$ template. Cycling was performed using a Mastercycler (Eppendorf) under the following conditions: $15 \mathrm{~min}$ at $94^{\circ} \mathrm{C} ; 45$ cycles at $94^{\circ} \mathrm{C}$ for $20 \mathrm{sec}$, annealing at $62^{\circ} \mathrm{C}$ for $30 \mathrm{sec}$ and extension $72^{\circ} \mathrm{C}$ for $1 \mathrm{~min}$; and finally, extension at $72^{\circ} \mathrm{C}$ for $3 \mathrm{~min}$. Shrimp alkaline phosphotase (SAP) mixture $(2 \mu \mathrm{l})$ was then added to each reaction. The reactions were vortexed briefly, centrifuged at 3,000 $\mathrm{rpm}$ for $5 \mathrm{~min}$, and incubated at $37^{\circ} \mathrm{C}$ for $20 \mathrm{~min}$, and $85^{\circ} \mathrm{C}$ for $5 \mathrm{~min}$.

RNA transcription was performed in a volume of $5 \mu \mathrm{l}$ containing RNase Free- $\mathrm{ddH}_{2} \mathrm{O}(3.15 \mu \mathrm{l}), 5 \times \mathrm{T}$ cleavage \& Polymerase buffer $(0.89 \mu \mathrm{l})$, T7 RNA \& DNA polymerase $(0.44 \mu \mathrm{l})$, T cleavage mix $(0.24 \mu \mathrm{l})$, DTT $(100 \mathrm{mM}, 0.22$ $\mu \mathrm{l})$, and RNAase A $(0.06 \mu \mathrm{l})$. After incubation at $37^{\circ} \mathrm{C}$ for $3 \mathrm{hr}, 6 \mathrm{mg}$ Clean Resin (Sequenom) was added to desalt RNA. MassARRAY MS (Bruker-Sequenom USA) was used to analyze the data.

\section{Cell culture and transfection}

cDNA of $C / E B P \alpha$ gene was cloned into pcDNA3.1(-) vector and confirmed by sequencing after cloning into the pcDNA3.1(-) expression vector. HeLa cells were initially obtained from ATCC (American Type Culture Collection, Manassas, VA) and maintained in our lab. Non-transfected HeLa cells and those transfected with pcDNA3.1(-) were used as controls. HeLa cells were plated at $1-2 \times 10^{5}$ cells per well in a six-well cell culture plate 12-24 hr before the transfection. Two $\mu$ g of C/EBP $\alpha$ constructs and control plasmids pcDNA3.1 were mixed with $6 \mu \mathrm{l}$ of Lipofect AMINE 2000 (Invitrogen). The mixture was incubated at room temperature for $20 \mathrm{~min}$. After washing the cells with $1 \times$ PBS, the DNA/ Lipofect AMINE 2000 mixtures were transferred to HeLa cells. Plasmids pcDNA3.1 were also transferred into separate HeLa cells as controls. Transfected HeLa cells were then incubated at $37^{\circ} \mathrm{C}$ in the $5 \% \mathrm{CO}_{2}$ for $24 \mathrm{hr}$. The effect of C/EBP $\alpha$ overexpression was determined by measuring immunofluorescence luciferase activity using an assay system according to the manufacturer's protocol (Promega). Each experiment was repeated with multiple batches of cells.

\section{Cell survival rate assay using MTT}

The survival rate of HeLa cells transfected by C/EBP $\alpha$ pcDNA3.1 construct and pcDNA3.1, and non-transfected HeLa cells, was determined using the 3-(3,4-dimethylthiazol-2-yl)-2,5-diphenyltetrazolium bromide (MTT) assay. The HeLa cells transfected with C/EBP $\alpha$ pcDNA3.1 constructs, transfected cells with pcDNA3.1, and nontransfected HeLa Cells were seeded in 96-well plates (Falcon; Becton Dickinson Labware) at $0.6 \times 10^{4}$ cells per well in DMEM containing 10\% FBS. The cells were incubated for $24 \mathrm{hr}$ at $37^{\circ} \mathrm{C}$; the number of cells was quantified with the MTT cell growth assay kit according to the manufacturer's instruction. Briefly, $20 \mu \mathrm{l}$ of MTT solution was added to each well, incubated for $4 \mathrm{hr}$, and then scanned at $570 \mathrm{~nm}$ by microplate reader MTP-300 (Corona); the quantification was repeated 10 times. The statistics were obtained from ten individual experiments by analysis of variance.

\section{Cell migration assays}

Cells were serum-starved overnight. The top chambers of $6.5 \mathrm{~mm}$ Corning Costar transwells (Corning, NY, New York, USA) were loaded with $0.2 \mathrm{ml}$ of cells $\left(5 \times 10^{5}\right.$ cells $/ \mathrm{ml}$ ) in serum-free media. DMEM media containing $20 \%$ FBS $0.6 \mathrm{ml}$ was added to the bottom wells and the cells were then incubated at $37^{\circ} \mathrm{C}$ overnight. Cells on the top layer were removed and the images of the cells at the bottom of the membrane were captured using a canon camera microscope $(\times 200)$. The statistics were obtained from five individual experiments by analysis of variance.

\section{Statistics}

Statistical analysis was performed using SPSS 17.0 software. $\mathrm{C} / \mathrm{EBP} \alpha$ protein levels were compared between cervical carcinoma and chronic cervicitis using nonparametric test. C/EBP $\alpha$ mRNA level in cervical carcinoma tissues and the adjacent normal tissues was analyzed by Student ' $\mathrm{t}$ ' test. The promoter of $C / E B P \alpha$ gene methylation by MALDI TOF MassARRAY method was analyzed with Wilcoxon Rank Sum Test.

\section{Results}

C/EBPa protein level in cervical carcinoma tissues and chronic cervicitis tissues

$\mathrm{C} / \mathrm{EBP} \alpha$ protein level was strongly positive (score 4) in the nuclei of chronic cervicitis cells. There were 70 strong staining (score 4), 19 medium staining (score 3), 20 weak staining (score 2) and 16 negative staining (score 0-1) in chronic cervicitis tissues. There were, however, 44 strong staining (score 4), 59 medium 


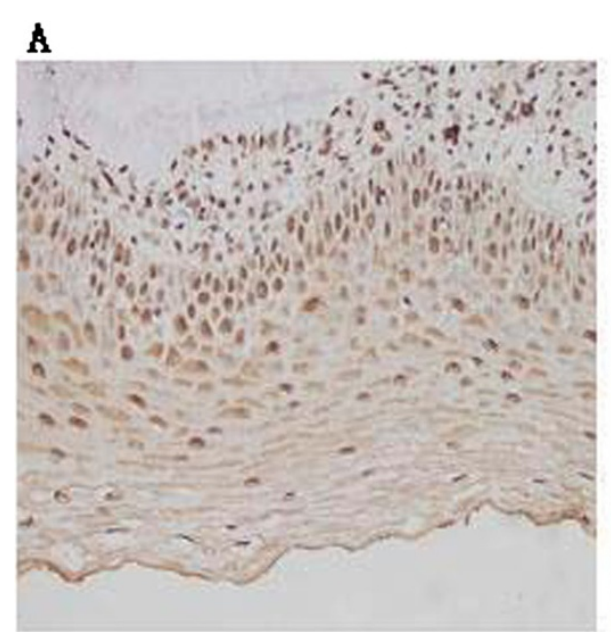

\section{B}
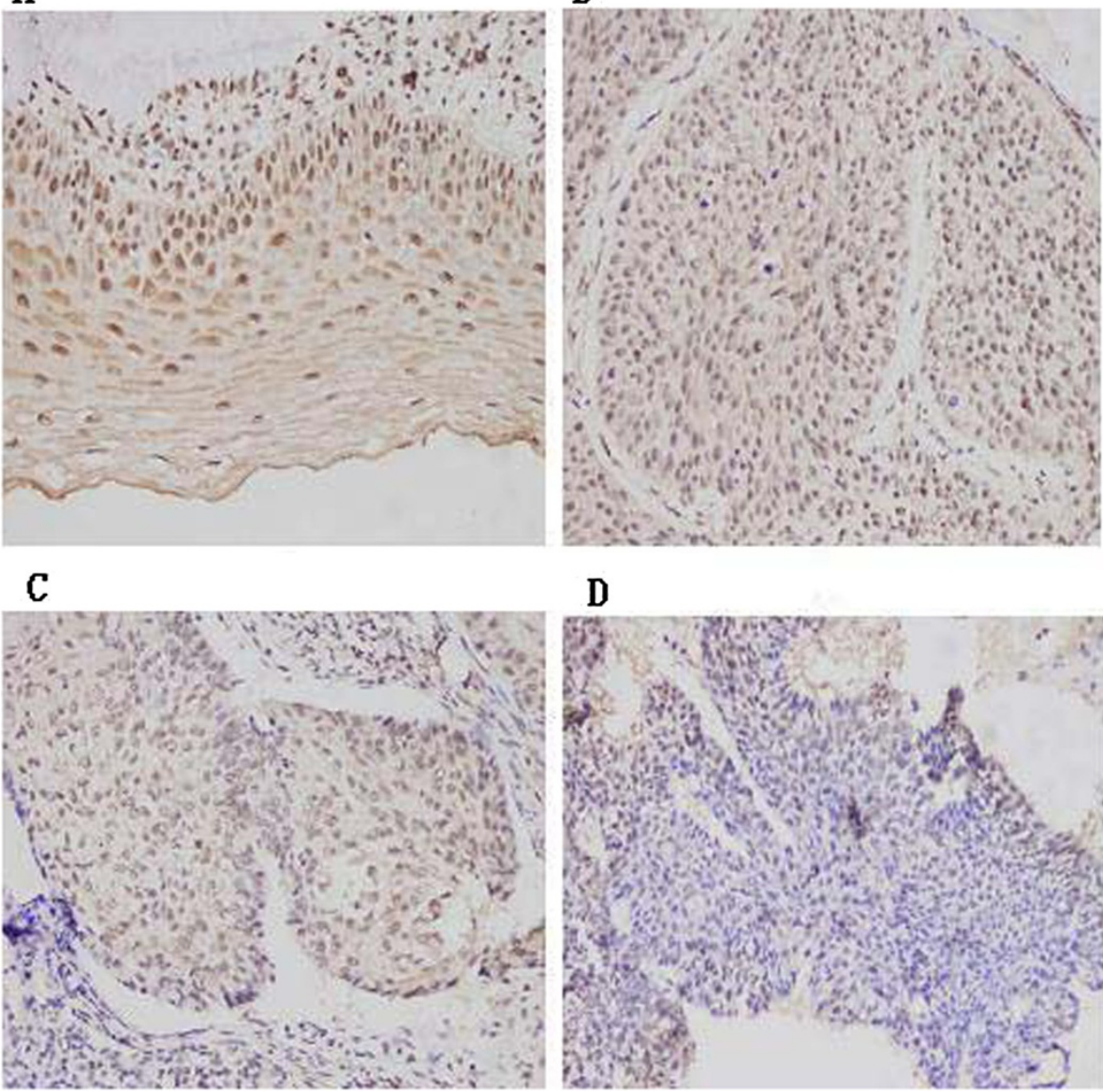

\section{D}

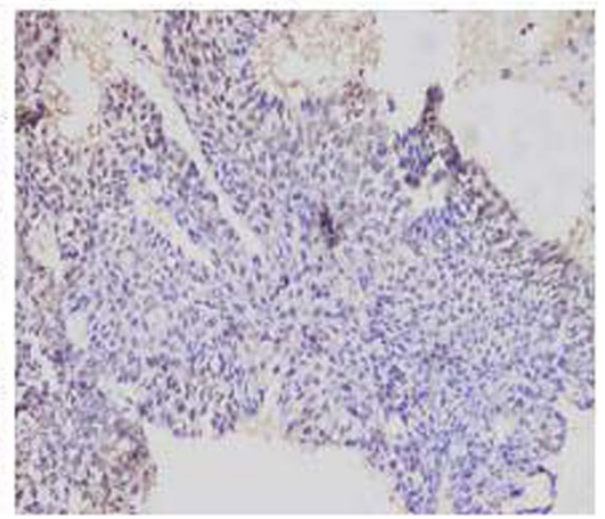

Figure 1 Expression level of C/EBPa protein in chronic cervicitis tissues and cervical carcinoma measured by immunohistochemistry (200x Magnification). (A) chronic cervicitis (B) well-differentiated cancer (C) moderately differentiated cancer (D) poorly differentiated cancer.

staining (score 3), 34 weak staining (score 2) and 22 negative staining (score 0-1) in cervical carcinoma. $\mathrm{C} / \mathrm{EBP} \alpha$ protein level was the highest in well-differentiated cervical carcinoma, followed by moderately differentiated cervical cancer, and was the lowest in poorly differentiated cervical cancer (Figure 1). Thus, the difference between chronic cervicitis and cervical carcinoma in $\mathrm{C} / \mathrm{EBP} \alpha$ protein level was significant $(P<0.001)$ (Table 1$)$. C/EBP $\alpha$ protein level in the well-differentiated cervical carcinoma was significantly higher than that in the moderately differentiated cervical carcinoma. Further, $\mathrm{C} / \mathrm{EBP} \alpha$ protein level in moderately differentiated cervical carcinoma was significantly higher than that in poorly differentiated cervical carcinoma $(P<0.001)$ (Table 2$)$. Immunohistochemistry staining of serial sections of tissues showed that expression of $\mathrm{C} / \mathrm{EBP} \alpha$ protein was increased whereas expression of Ki67 protein expression was reduced in chronic cervicitis. However, in CIN3 (carcinoma in situ) and squamous cell carcinoma, $\mathrm{C} / \mathrm{EBP} \alpha$ protein expression was decreased whereas Ki-67 protein expression was increased (Figure 2). Therefore, it is possible that $\mathrm{C} / \mathrm{EBP} \alpha$ protein could regulate cervical cell proliferation.

\section{C/EBPa mRNA level in cervical carcinoma and normal cervical tissues}

Fifteen cervical carcinoma tissues and their corresponding normal cervical tissues were examined for $C E B P \alpha$ gene expression by real time quantitative RT-PCR. The average $C E B P \alpha$ mRNA level was $3.07 \pm 1.04$ in cervical cancer tissues and $5.63 \pm 2.98$ in their corresponding normal

Table 1 Expression of C/EBPa protein in the chronic cervicitis tissues and cervical carcinoma tissues

\begin{tabular}{|c|c|c|c|c|c|c|}
\hline Tissues & Number & Score 4 & Score 3 & Score 2 & Score $0-1$ & \\
\hline Chronic cervicitis tissues & 125 & 70 & 19 & 20 & 16 & $P<0.001$ \\
\hline Cervical squamous cell carcinoma tissues & 159 & 44 & 59 & 34 & 22 & \\
\hline
\end{tabular}


Table 2 Expression level of C/EBPa protein in cervical squamous carcinoma of different grades of pathology

\begin{tabular}{lccccc}
\hline Tissues & Number & \multicolumn{4}{c}{ C/EBPa protein expression } \\
\cline { 3 - 6 } & & Score 4 & Score 3 & Score 2 & Score 0-1 \\
\hline Well differentiated carcinoma & 38 & 13 & 9 & 10 & 6 \\
Moderately differentiated carcinoma & 99 & 31 & 49 & 10 & $9<0.001$ \\
Poorly differentiated carcinoma & 22 & 0 & 1 & 14 & 7 \\
\hline
\end{tabular}

cervical tissues (Figure 3A). The difference between cervical tissues and their corresponding normal cervical tissues was significant $(t=-3.150, P<0.01)$. Thus, the expression of $C E B P \alpha$ gene was reduced significantly in cervical carcinoma tissues.

\section{Methylation in the promoter of C/EBPa gene analysis}

Forty-seven cervical carcinoma tissues and 25 normal tissues were analyzed for methylation in the promoter of $C / E B P \alpha$ gene by MALDI TOF MassARRAY. We found that the rate of $C / E B P \alpha$ gene methylation in $\mathrm{CpG} 5$,
CpG-14.15, CpG-19.20 were significantly higher in cervical tissues than in normal cervical tissues $(P<0.05$, $P<0.01, P<0.05$, respectively; Figure $3 \mathrm{~B})$. Methylation in the promoter of $C / E B P \alpha$ gene, thus, may have caused the reduction in the expression of this gene.

C/EBPa gene construct transfected into HeLa cells inhibit cell growth and decrease cell migration

The proliferation of HeLa cells transfected by $\mathrm{C} / \mathrm{EBP} \alpha$ pcDNA3.1 construct was inhibited significantly compared to those transfected by pcDNA3.1 plasmid and non-

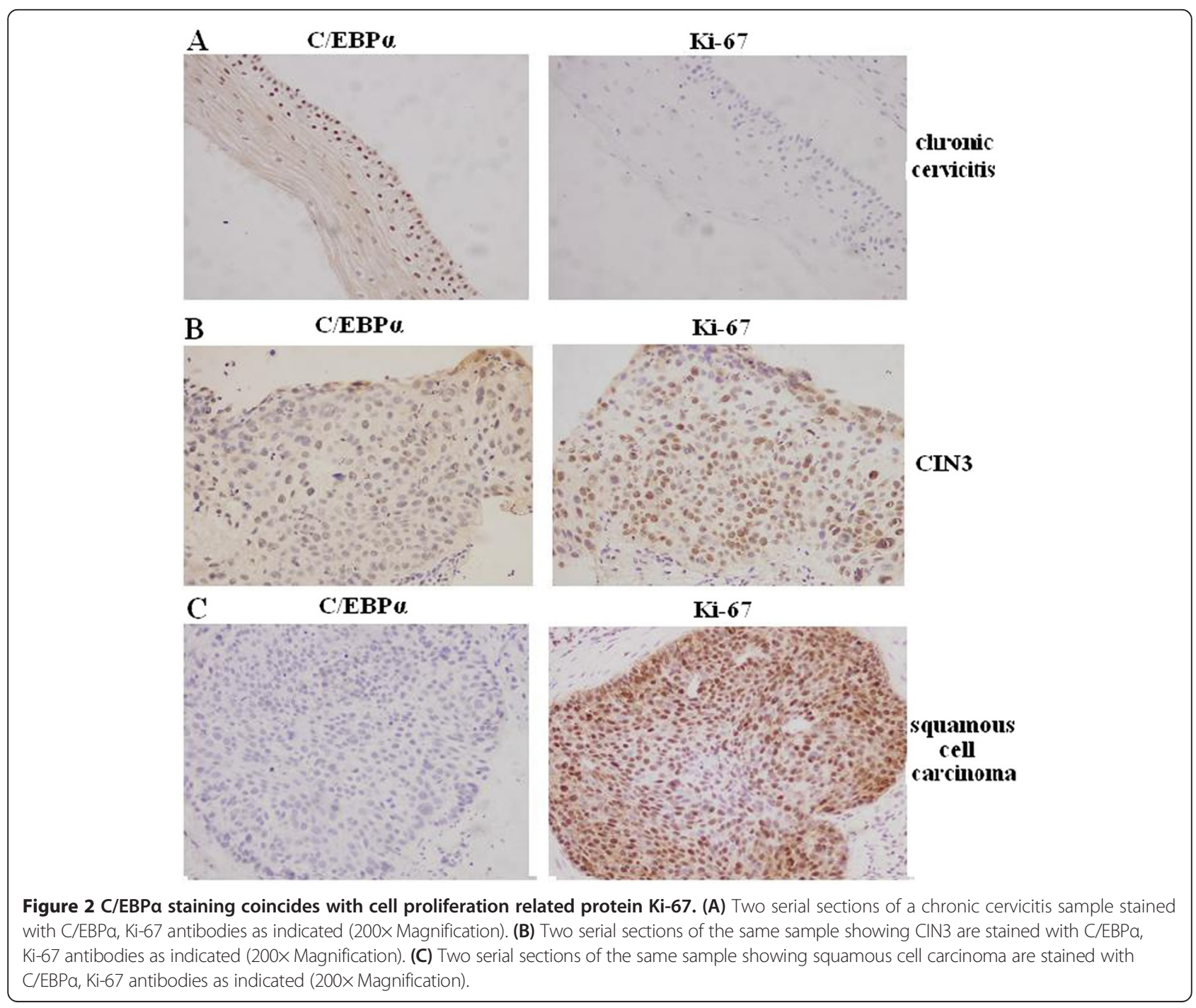




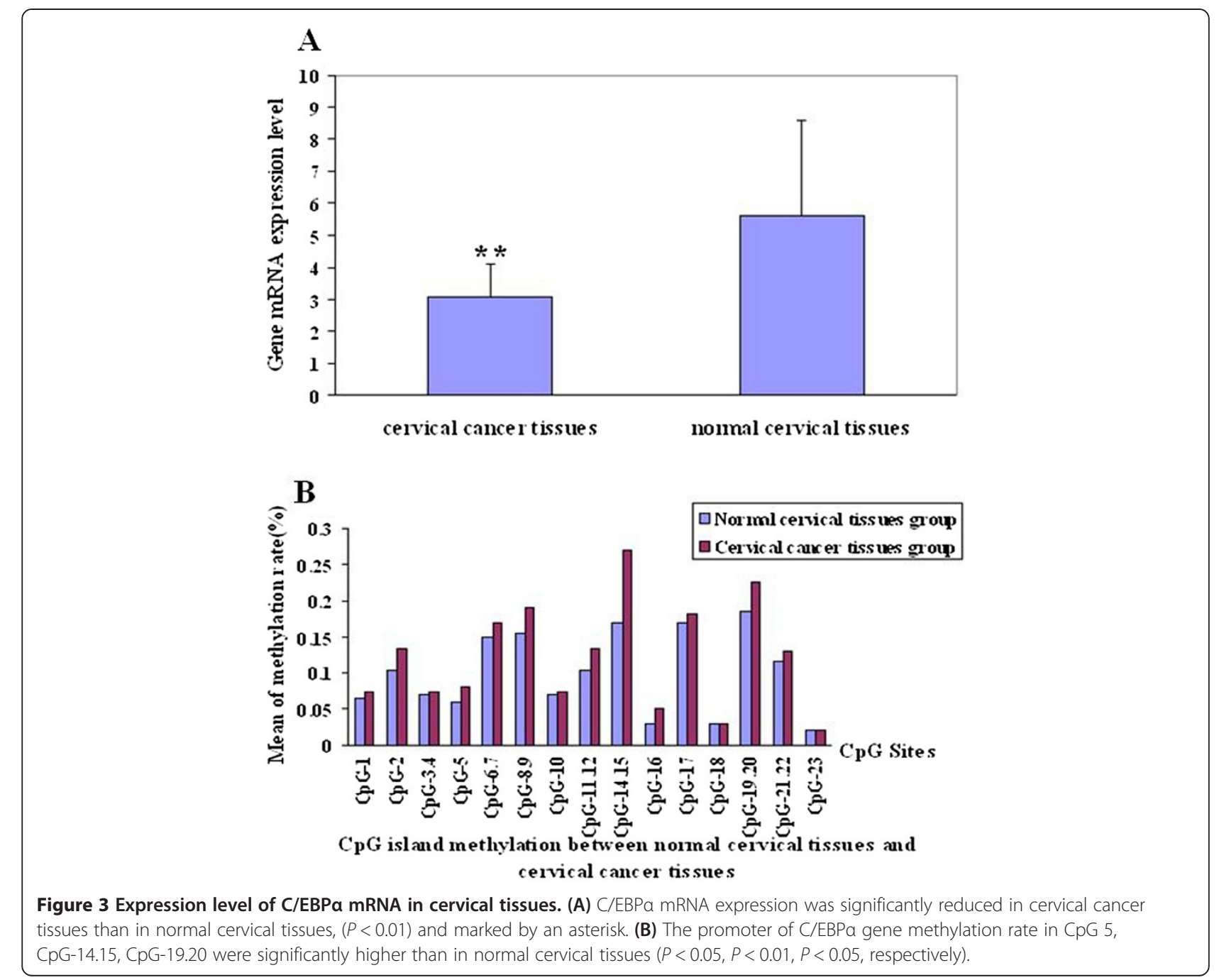

transfected HeLa cells using MTT assay $(P<0.001)$ (Figure $4 \mathrm{~A})$. This study indicates that $C / E B P \alpha$ gene may inhibit HeLa cell proliferation. To assess whether overexpression of $\mathrm{C} / \mathrm{EBP} \alpha$ is sufficient to reduce cell migration, we measured the migration of HeLa cells using transwell migration assays. The number of HeLa cells migrated in C/EBP $\alpha$ pcDNA3.1 construct transfected group is significantly less than that in the two control groups, i.e. pcDNA3.1 plasmid transfected group (without C/EBP $\alpha$ gene) and the HeLa cells not subject to transfection (Figure $4 \mathrm{~B}$ ). Thus, the expression of $\mathrm{C} / \mathrm{EBP} \alpha$ protein in HeLa appears to inhibit cell migration. The numbers of migration cells are significantly different between C/EBP $\alpha$ pcDNA3.1 construct transfected group and the two control groups with mean \pm SD $(n=5)(P<0.001)$ (Figure 4C).

\section{Discussion}

Proteins in the C/EBP family are fundamental to the control of differentiation and proliferation of many adult tissues. $C / E B P \alpha$ gene is involved in mitotic growth arrest and differentiation of numerous cell types. Downregulation of $C / E B P \alpha$ in keratinocytes can be permissive for cell proliferation and may block squamous differentiation. Reduction of C/EBPa gene expression occurred in hepatocellular carcinoma, skin carcinoma and lung cancer, in particular in lung adenocarcinomas, which had the most significant and frequent reduction in $C / E B P \alpha$ gene expression [4]. $C / E B P \alpha$ is aberrantly silenced in pancreatic cancer cells and restored $C / E B P \alpha$ gene expression markedly suppressed proliferation of pancreatic cancer cells [13]. In gastric carcinoma, loss of $\mathrm{C} / \mathrm{EBP} \alpha$ is associated with the switch from cellular differentiation to cellular proliferation, presumably as a result of the activation of Ras/MAPK pathway [14]. In addition, methylation in the promoter of $C / E B P \alpha$ gene occurred at a rate of $24 \%$ in dedifferentiated liposarcoma (DLPS). While treatment with demethylating agents could restore $C / E B P \alpha$ expression in DLPS cells, it was anti-proliferative and pro-apoptotic in vitro and reduced tumor growth in vivo [15]. $C / E B P \alpha$ gene is located in 19q13, gene loss at this site of 


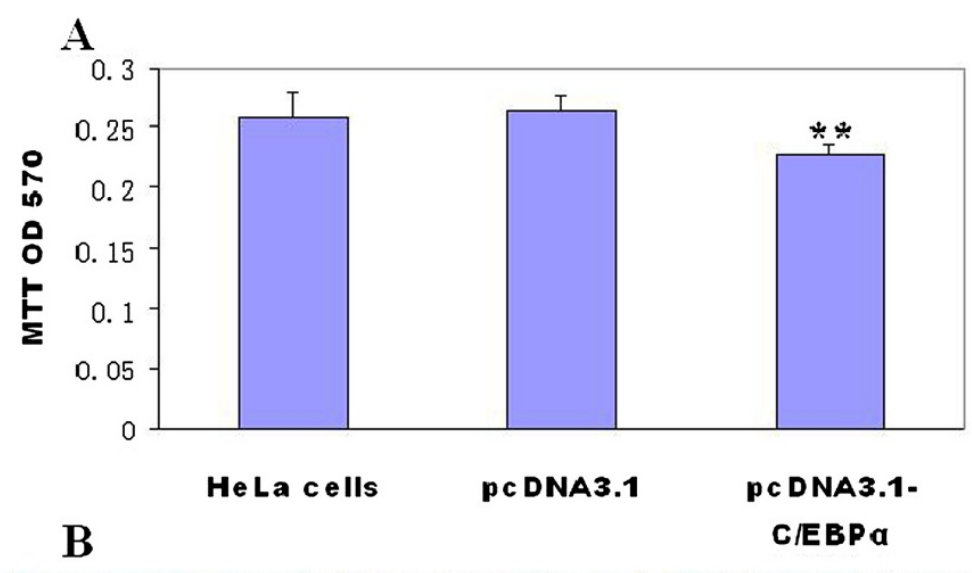

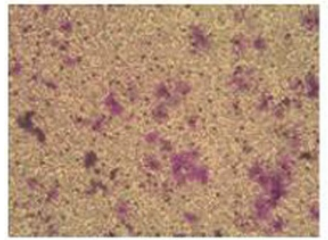

HeLa Cells

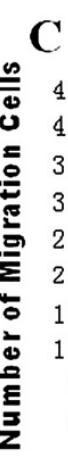

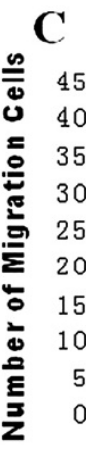
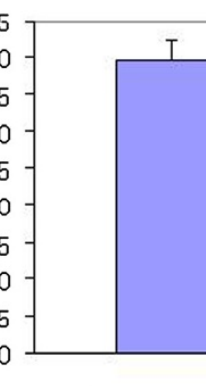

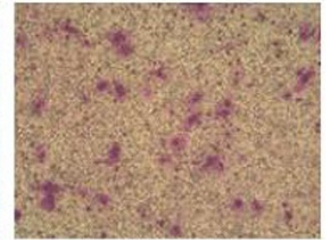

pCDNA3.1

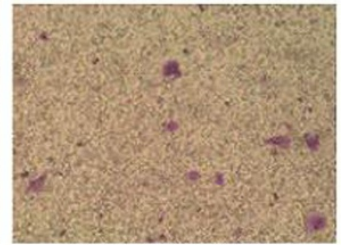

PCDNA3.1-C/EBPa

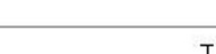


protection for thinning of the epithelium and chemicalinduced skin cancer [20].

In the mouse model of AML, $\mathrm{C}$-terminal C/EBP $\alpha$ mutations increase the proliferation of long-term hematopoietic stem cells (LT-HSC) whereas $\mathrm{N}$-terminal C/EBP $\alpha$ mutations allow formation of leukemia initiating cells [21]. The evidence available indicates that impaired C/EBP $\alpha$ function contributes directly to the development of AML; thus restoring C/EBP $\alpha$ function represents a promising target for novel therapeutic strategies in AML [22]. The consequential up-regulation of C/EBP $\alpha$ and IGFBP5 by curcumin is crucial to the suppression of oral carcinogenesis [23]. In acute promyelocytic leukemia cancer-initiating cells, C/EBP $\alpha$ expression is downregulated, possibly through a methylation-dependent mechanism, indicating that $C / E B P \alpha$ deregulation may contribute to the transformation of these cells [24]. The ectopic expression of $C / E B P \alpha$ can induce the monocytic differentiation of myelomonocytic leukemic cells through the down-regulation of Myc gene [25].

The expression of $C / E B P \alpha$ gene in cervical cancer is poorly understood. We found that $\mathrm{C} / \mathrm{EBP} \alpha$ protein expression was significantly different between chronic cervicitis and cervical squamous cell carcinoma. Moreover, the expression level of $\mathrm{C} / \mathrm{EBP} \alpha$ protein in the well-differentiated cervical carcinoma was significantly higher than that in the moderately differentiated cervical carcinoma. Furthermore, the expression level of C/EBP $\alpha$ protein in the moderately differentiated cervical carcinoma was higher than that in the poorly differentiated cervical carcinoma. Clearly, $\mathrm{C} / \mathrm{EBP} \alpha$ protein expression level was related to the grade of pathology. Our results indicate that we may be able to interfere the carcinogenesis of cervical cancer by regulating the expression of $C / E B P \alpha$ gene. Thus, C/EBP $\alpha$ protein could potentially be a target for cervical cancer treatment and changes in the expression of $\mathrm{C} / \mathrm{EBP} \alpha$ protein could be of significance to the early diagnosis of cervical cancer.

In addition, C/EBP $\alpha$ protein increased expression whereas $\mathrm{Ki}-67$ protein decreased expression in chronic cervicitis tissues. However, C/EBP $\alpha$ protein decreased expression whereas Ki-67 protein increased expression in cancer tissues (Figure 2). Thus, C/EBP $\alpha$ may affect cervical cell proliferation. These results are similar to that obtained by MTT assay of HeLa cells (Figure 4C).

We analyzed the $C / E B P \alpha$ mRNA expression in cervical squamous cell carcinoma and their corresponding normal tissues. The C/EBP $\alpha$ mRNA expression level was significantly higher in cervical squamous cell carcinoma tissues than in their corresponding normal cervical tissues. Our results indicated that $C / E B P \alpha$ mRNA expression level was decreased in invasive cervical cancer. In addition, methylation in the promoter of $C / E B P \alpha$ gene in cervical cancer tissues was significantly higher than in normal cervical tissues. It is possible that the methylation in the promoter of $C / E B P \alpha$ gene leads to decreased expression of this gene.

The full length mRNA of $C / E B P \alpha$ gene was cloned in pcDNA3.1 eukaryotic expression vector. The C/EBPa gene construct and pcDNA3.1 vector were transfected into HeLa cells. HeLa cells transfected by $C / E B P \alpha$ gene construct were significantly lower in growth than the HeLa cells transfected by pcDNA3.1 plasmid and the non-transfected HeLa cells by MTT assay. In addition, after being transfected by $C / E B P \alpha$ gene construct, the migration of HeLa cells was significantly reduced than those transfected by pcDNA3.1 plasmid and the nontransfected HeLa cells by matrigel-coated transwell migration assays. These results indicate that $C / E B P \alpha$ gene may inhibit the growth of HeLa cells and decrease the invasion of HeLa cells. Therefore, C/EBP $\alpha$ gene may act as a tumor suppressor gene for cervical carcinoma.

\section{Conclusions}

In summary, the expression of $C / E B P \alpha$ gene and $C / E B P \alpha$ protein was down-regulated in cervical carcinoma tissues, possibly caused by methylation in the promoter region of this gene. Reduced expression of $C / E B P \alpha$ gene and $\mathrm{C} / \mathrm{EBP} \alpha$ protein appears to be associated with cervical tumorigenesis. By gene transfection methods, we showed that $C / E B P \alpha$ gene could inhibit the growth of HeLa cells and reduce the invasion of HeLa cells. Therefore, $C / E B P \alpha$ gene may be a tumor suppressor gene in HeLa cells and plays an important role in cervical carcinogenesis.

\section{Competing interests}

The authors declare that they have no competing interests.

\section{Authors' contributions}

ZP carried out the molecular genetic studies, participated in the gene analysis and wrote the manuscript. WZ carried out the

immunohistochemistry Staining. JZ and DL carried out the qRT-PCR. RG and $X G$ carried out gene methylation analysis. HH carried out gene transfection. FL participated in the design of the study and performed the statistical analysis. SQ and RS participated in experimental design and wrote the manuscript. All authors read and approved the final manuscript.

\section{Acknowledgments}

This work was supported by the National Natural Science Foundation of China (grant numbers 30860302 and 30660193), The Fund of Plan in the Year of 2011 for Promotion with the Region of Americas and Oceania Cooperation in Scientific Research and Cultivation of High Level Talent Project, The International Science and Technology Collaboration Projector of Xinjiang Production and Construction Corps (grant numbers 2013BC003), The Youth Scientific Innovation Special Grant of Xinjinag Production and Construction Corps (grant numbers 2012CB018) and an International Science and Technology of Collaboration and Exchange Special Grant (grant numbers 2010DFB34100). RS acknowledges the funding support from the Australia-China Science \& Research Fund (ACSRF00980).

\section{Author details}

'Department of Biochemistry and Molecular Biology, School of Medicine, Shihezi University, Xinjiang Endemic and Ethnic Disease and Education Ministry Key Laboratory, Shihezi, Xinjiang 832002, China. ${ }^{2}$ Department of Biochemistry and Molecular Biology, Basic Medical Science of Tongji Medical College, Huazhong University of Science and Technology, Wuhan, Hubei 430030, China. ${ }^{3}$ Genecology Research Centre, Faculty of Science, Health, 
Education and Engineering, University of the Sunshine Coast, Maroochydore DC, Brisbane, Queensland 4558, Australia.

Received: 2 November 2013 Accepted: 22 May 2014 Published: 10 June 2014

\section{References}

1. Siegel R, Naishadham D, Jemal A: Cancer statistics, 2012. CA Cancer J Clin 2012, 62(1):10-29.

2. Pan Z, Li J, Pan X, Chen S, Wang Z, Li F, Qu S, Shao R: Methylation of the RASSF1A gene promoter in Uigur women with cervical squamous cell carcinoma. Tumori 2009, 95(1):76-80.

3. Rishi V, Bhattacharya P, Chatterjee R, Rozenberg J, Zhao J, Glass K, Fitzgerald P, Vinson C: CpG methylation of half-CRE sequences creates C/EBPa binding sites that activate some issue-specific genes. Proc Natl Acad Sci U S A 2010, 107(47):20311-20316

4. Shim M, Powers KL, Ewing SJ, Zhu S, Smart RC: Diminished expression of C/EBPalpha in skin carcinomas is linked to oncogenic Ras and reexpression of C/EBPalpha in carcinoma cells inhibits proliferation. Cancer Res 2005, 65(3):861-867.

5. Wang H, lakova P, Wilde M, Welm A, Goode T, Roesler WJ, Timchenko NA: C/EBPa arrests cell proliferation through direct inhibition of Cdk2 and Cdk4. Mol Cell 2001, 8(4):817-828

6. Satoh $T$, Kidoya $H$, Naito $H$, Yamamoto M, Takemura N, Nakagawa K Yoshioka Y, Morii E, Takakura N, Takeuchi O, Akira S: Critical role of Trib1 in differentiation of tissue-resident M2-like macrophages. Nature 2013, 495(7442):524-528.

7. Di Tullio A, Graf T: C/EBPa bypasses cell cycle-dependency during immune cell transdifferentiation. Cell Cycle 2012, 11(14):2739-2746.

8. Loomis KD, Zhu S, Yoon K, Johnson PF, Smart RC: Genetic ablation of CCAAT/enhancer binding protein alpha in epidermis reveals its role in suppression of epithelial tumorigenesis. Cancer Res 2007, 67(14):6768-6776.

9. Sato A, Yamada N, Ogawa Y, Ikegami M: CCAAT/enhancer-binding proteinsuppresses lung tumor development in mice through the p38a MAP kinase pathway. PLoS One 2013, 8(2):e57013.

10. Pan Z, Chen S, Pan X, Wang Z, Han H, Zheng W, Wang X, Li F, Qu S, Shao R: Differential gene expression identified in Uigur women cervical squamous cell carcinoma by suppression subtractive hybridization. Neoplasma 2010, 57(2):123-128.

11. Ko CY, Hsu HC, Shen MR, Chang WC, Wang JM: Epigenetic silencing of CCAAT/enhancer-binding protein delta activity by YY1/polycomb group/ DNA methyltransferase complex. J Biol Chem 2008, 283(45):30919-30932.

12. Schatz P, Dietrich D, Schuster M: Rapid analysis of CpG methylation patterns using RNase T1 cleavage and MALDI-TOF. Nucleic Acids Res 2004, 32(21):e167.

13. Kumagai T, Akagi T, Desmond JC, Kawamata N, Gery S, Imai Y, Song JH, Gui D, Said J, Koeffler HP: Epigenetic regulation and molecular characterization of C/EBPalpha in pancreatic cancer cells. Int J Cancer 2009, 124(4):827-833.

14. Regalo G, Resende C, Wen X, Gomes B, Durães C, Seruca R, Carneiro F, Machado JC: C/EBP alpha expression is associated with homeostasis of the gastric epithelium and with gastric carcinogenesis. Lab Invest 2010, 90(8):1132-1139.

15. Taylor BS, DeCarolis PL, Angeles CV, Brenet F, Schultz N, Antonescu CR Scandura JM, Sander C, Viale AJ, Socci ND, Singer S: Frequent alterations and epigenetic silencing of differentiation pathway genes in structurally rearranged liposarcomas. Cancer Discov 2011, 1(7):587-597.

16. Crago AM, Socci ND, DeCarolis P, O'Connor R, Taylor BS, Qin LX, Antonescu $C R$, Singer S: Copy number losses define subgroups of dedifferentiated liposarcoma with poor prognosis and genomic instability. Clin Cancer Res 2012, 18(5):1334-1340.

17. Zhang S, Jiang T, Feng L, Sun J, Lu H, Wang Q, Pan M, Huang D, Wang X, Wang $L$, Jin $H$ : Yin Yang-1 suppresses differentiation of hepatocellular carcinoma cells through the downregulation of CCAAT/enhancer binding protein alpha. J Mol Med (Berl) 2012, 90(9):1069-1077.

18. Eyholzer M, Schmid S, Wilkens L, Mueller BU, Pabst T: The tumour-uppressive miR-29a/b1 cluster is regulated by CEBPA and blocked in human AML. Br J Cancer 2010, 103(2):275-284.

19. Zhang C, Chi YL, Wang PY, Wang YQ, Zhang YX, Deng J, Lv CJ, Xie SY: miR511 and miR-1297 inhibit human lung adenocarcinoma cell proliferation by targeting oncogene TRIB2. PLoS One 2012, 7(10):e46090.
20. Patrick BA, Jaiswal AK: Stress-induced NQO1 controls stability of C/EBPa against $20 \mathrm{~S}$ proteasomal degradation to regulate $\mathrm{p} 63$ expression with implications in protection against chemical-induced skin cancer. Oncogene 2012, 31(40):4362-4371.

21. Bereshchenko O, Mancini E, Moore S, Bilbao D, Månsson R, Luc S, Grover A Jacobsen SE, Bryder D, Nerlov C: Hematopoietic stem cell expansion precedes the generation of committed myeloid leukemia-initiating cells in C/EBPalpha mutant AML. Cancer Cell 2009, 16(5):390-400.

22. Pabst T, Mueller BU: Complexity of CEBPA dysregulation in human acute myeloid leukemia. Clin Cancer Res 2009, 15(17):5303-5307.

23. Chang KW, Hung PS, Lin IY, Hou CP, Chen LK, Tsai YM, Lin SC: Curcumin upregulates insulin-like growth factor binding protein-5 (IGFBP-5) and C/EBPalpha during oral cancer suppression. Int J Cancer 2010, 127(1):9-20

24. Guibal FC, Alberich-Jorda M, Hirai H, Ebralidze A, Levantini E, Di Ruscio A Zhang P, Santana-Lemos BA, Neuberg D, Wagers AJ, Rego EM, Tenen DG: Identification of a myeloid committed progenitor as the cancer-initiating cell in acute promyelocytic leukemia. Blood 2009, 114(27):5415-5425.

25. Matsushita $H$, Nakajima $H$, Nakamura $Y$, Tsukamoto $H$, Tanaka $Y$, Jin $G$, Yabe M, Asai S, Ono R, Nosaka T, Sugita K, Morimoto A, Hayashi Y, Hotta T, Ando $\mathrm{K}$, Miyachi $\mathrm{H}$ : C/EBPalpha and C/EBPvarepsilon induce the monocytic differentiation of myelomonocytic cells with the MLL-chimeric fusion gene. Oncogene 2008, 27(53):6749-6760.

doi:10.1186/1471-2407-14-417

Cite this article as: Pan et al:: Down-regulation of the expression of CCAAT/enhancer binding protein a gene in cervical squamous cell carcinoma. BMC Cancer 2014 14:417.

\section{Submit your next manuscript to BioMed Central and take full advantage of:}

- Convenient online submission

- Thorough peer review

- No space constraints or color figure charges

- Immediate publication on acceptance

- Inclusion in PubMed, CAS, Scopus and Google Scholar

- Research which is freely available for redistribution
C Biomed Central 